\title{
MAPPING FOREST ECOSYSTEM SERVICES: A REVIEW
}

\author{
S. Ajrhough ${ }^{1}$, M.Maanan $^{1}$, H. Mharzi Alaoui ${ }^{2}$, H. Rhinane ${ }^{1}$, E. H. El Arabi ${ }^{1}$
}

${ }^{1}$ Faculty of Sciences Ain Chock, Department of Earth Sciences, University Hassan II, Casablanca, Morocco

${ }^{2}$ National Center for Forest Climate Risk Management, Rabat, Morocco

\author{
Commission IV
}

\begin{abstract}
KEY WORDS: Forest Ecosystem Services, Modelling, Mapping, Trade-offs, Management Regimes, Carbon Sequestration
\end{abstract}
\begin{abstract}
:
Managing multiple ecosystem services (ES) across forest landscape, constitute a growing field of research. It represents a key challenge that attempts to optimize the trade-offs among provisioning, supporting, regulating and cultural ES. Here, we review approaches and shortcomings on some anterior FES studies. Three main components are presented, 1) an overview of the current state of research, 2) a summary of main methods adopted 3) an identification of principal approaches' restrictions. Several conclusions emerge: most of the studies focus on a limited number of FES which might undermine the long-term provision of other FES, or converge to using free software models which are practical and low-cost but require enormous data. This reveals how the lack of existing inventories and evaluations impacts the choice of methodologies and lead to use indirect methods of measurement. However, researches that aim to understand the relationships and conflicts among multiple FES and seeks to find out the best management regime will improve our ability to sustainably fulfil economic, ecologic and social goals.
\end{abstract}

\section{INTRODUCTION}

Ecosystem services represent direct and indirect benefits that people obtain from ecosystems (MEA, 2005). Many crucial ecosystem services are provided by forests (Gamfeldt et al., 2013; García-Nieto et al., 2013; Vanhanen et al., 2012). They supply food and timber, regulate local and global climate, remove pollutants, enhance soil retention and water quality, and improve landscape aesthetics (Chiabai et al.,2011;De Groot and van der Meer,2010). These benefits have been undervalued since they are not traded in conventional markets and are in fact difficult to value (Ninan et al,2016).

Due to the population expansion and the economic growth; demands are highly increasing (Vitousek et al., 1997), which have caused severe ecosystem degradation and biodiversity loss (MEA, 2005; Rapport et al., 1998). These impacts can conduct to changes in the state of ecosystem functioning (IPCC,2001), which in turn affect the overall provision of forest ecosystem goods and services, and ultimately have a negative impact on human-wellbeing (Liebhold et al,2017; Wagner et al, 2014).

Improving the sustainability of natural resources use and managing multiple forest ecosystem services become key challenges that attempts to optimize the trade-offs and synergies among ecosystem services and the way they are driven by management interventions (Rodríguez et al., 2006).

Several researches have examined the relationships among ecosystem services and the effects of management on their supply in forests (e.g. Bradford and D'Amato, 2012; Brandt et al., 2014). A literature survey was run by (Tol,2009), have showed an exponential increase in the number of papers published in international peer reviewed journals on the topic of climate change, from 1714 to 11652 papers, respectively in 1995 and 2008. Recent literature has moved forward to explore methodologies that can examine the relationship between ecosystem services and climate change, in order to explain how changes in climate conditions may affect the provision of ecosystem services (Ding et al ,2016).
In this study, we review research that focus on the environmental and monetary assessment of forest ecosystem services and spotlight studies examining trade-offs between them. We also identify relevant approaches used by scientists and examine their shortcomings

\section{METHODS AND MATERIALS}

Our review is based on published research since 2001s with the terms "forest ecosystem services", forest ecosystem services management", and "forest ecosystem valuation". We have selected 104 articles that allow us to draw representative conclusions. By highlighting studies that aim to analyse the environmental and economic assessments, we reduced this sample to 47 publications and concentrate on 7 recent published papers (2014-2018) held in different study areas. We have classified the papers according to the valuated service and the type of the valuation (environmental, economic or gather both of them (table 1).

A variety of methods are employed in these studies, the common approach is to proceed by an assessment of the chosen variables(table1). It is mostly about carbon stock, timber production, soil conservation and recreation. Each study has used a different method depending on the data availability and the singularities of the study area. 


\begin{tabular}{|c|c|c|}
\hline $\begin{array}{l}\text { Reference study } \\
\text { (autors and year) }\end{array}$ & Forest Ecosystem Service & $\begin{array}{c}\text { Type of valuation } \\
\text { (Environmental and } \\
\text { economic) }\end{array}$ \\
\hline Law et al (2014) & Carbon stocks & Environmental and economic \\
\hline $\begin{array}{l}\text { Trivino et al } \\
\qquad(2015)\end{array}$ & Carbon stocks/Timber production & Environmental and economic \\
\hline $\begin{array}{l}\text { Ninan et al } \\
\text { (2016) }\end{array}$ & $\begin{array}{l}\text { Water conservation/Soil conservation/Carbon sequestration } \\
\qquad / \text { Recreation }\end{array}$ & Economic \\
\hline $\begin{array}{l}\text { Lagregren et al } \\
\quad(2017)\end{array}$ & $\begin{array}{c}\text { Harvest/Net income/Storm damage resistance/Carbon storage and } \\
\text { sequestration/Biodiversity indicators }\end{array}$ & Environmental and economic \\
\hline $\begin{array}{l}\text { Pohjanmies et al } \\
\qquad \text { (2017) }\end{array}$ & $\begin{array}{l}\text { Timber production/Bilberry production/Carbon storage/Pest } \\
\text { regulation/Availability of deadwood resources }\end{array}$ & Environmental \\
\hline Ding et al (2016) & Supporting/Provisioning/Regulating/ Cultural services & Environmental and economic \\
\hline $\begin{array}{l}\text { Roces-Díaz et al } \\
\qquad(\mathbf{2 0 1 8 )}\end{array}$ & Supporting/Provisioning/Regulating/ Cultural services & Environmental and economic \\
\hline
\end{tabular}

Table 1: Summary of studied researches, the assessed ES and the type of valuation.

\section{RESULTS}

\subsection{Carbon stocks}

Forests help to mitigate climate change by sequestering $\mathrm{CO} 2$ from the atmosphere and storing it in different biomass pools (e.g., Powers et al., 2013). The main pools in forested ecosystems are the stores of above- and below-ground living biomass, necromass (litter, and woody debris), and soil organic matter (Houghton et al., 2012). To directly quantify the carbon stored in aboveground living forest biomass the only way is to harvest all trees in a known area, dry them and weigh the biomass (Gibbs et al ;2007), the carbon content represents $\approx 50 \%$ of biomass; Westlake 1966). While this method is applicable for a particular location, it is expensive, destructive and impractical for country-level analyses.

No direct methodology can yet measure forest carbon stocks. Thus, plenty efforts have gone into developing tools and models that can adjust or extrapolate data points to larger scales based on proxies measured in the field or from remote sensing instruments (Brown et al, 1982, 1993, Waring et al 1995, Brown 1997, Chave et al 2005, Saatchi et al 2007). The Intergovernmental Panel on Climate Change (IPCC) has produced a set of guidelines for estimating greenhouse gas inventories at different tiers of quality, ranging from Tier 1 (simplest to use; globally available data) up to Tier 3 (high resolution methods specific for each country and repeated through time) (Penman et al 2003, (chapter 3, 4), IPCC 2006, (chapter 2, 4)).

As a consequence, indirect methods of measuring carbon stocks and emissions, are frequent. (Law et al 2015) have distinguished two groups of proxies: Measurement-level proxies which can substitute for direct measurements, and Metric-level proxies that are a combination of several measurement-level proxies, generally derived through process-based modelling. He has used literature as a source of carbon stocks data in the Above-Ground
Biomass, the Below-Ground Biomass and the Soil Carbon, depending on the soil type and the peat depth. The estimation of potential emissions and potential emissions reduction were integrated into a process model to evaluate carbon flux through time, developed in

(Trivino et al,2015) have employed the (IPCC,2006) guidelines to calculate, the Carbon storage (the size of the carbon pool at a certain point in time), the Carbon sequestration (the rate of annual transfer of carbon between the atmosphere and forests) and the Carbon sequestered not extracted (refers to carbon excluded in harvested timber) considering the four most common tree species in boreal forests.

Otherwise, (Lagergren et al, 2017) applied a biogeochemical ecosystem model LPJ-GUESS that simulates the climate dependent vegetation development as well as the competition among age and species-specific cohorts (Smith et al 2001). It requires input data on temperature, precipitation, incoming shortwave radiation and $\mathrm{CO} 2$ concentrations (Kotlarski et al 2014). The total carbon stored in soil and biomass and the two components of annual carbon sequestration ( $\mathrm{C}$ in biomass, $\mathrm{C}$ in soil) can be obtained from the model simulations.

Similarly, (Ding et al 2016) based on biophysical data for EGS extracted from the FAOSTAT-Forestry database, have employed ATEAM and IMAGE 2.2 models to run a quantitative changes projection (wood forest products, carbon stocks) by deriving the percentage changes in forest areas and wood products for four IPCC storylines.

(Roce-Diaz et al 2018) have considered forest carbon sink capacity by using data from a consecutive forest survey and comparing plot-level data from 1989-1990 and 20002001.They have estimated the carbon stock change in above and belowground using a methodology defined by ( Vayreda et al. (2012). It consist on applying allometric equations per tree of each inventory's plot . The total $\mathrm{C}$ extent of each tree was calculated by multiplying biomass by the specific $\mathrm{C}$ fraction of 
the species obtained in a study carried out by (Gracia et al. $(2004 a, b))$.

\subsection{Timber Production}

Timber is one of the most notable resources derived from forest ecosystems (Brandt et al 2014). It provides substantial direct economic benefits, but can also act as powerful incentives to sustain forests and habitat (Fisher et al 2006, Ruddell et al 2007). Estimating the above-ground biomass can be done using allometric models (Chave et al 2014), extracted data from forest inventories (Roce-Diaz et al 2018) or using models such as MOTTI stand simulator which can statistically investigate forest growth and timber yield ( http://www.metla.fi/metinfo/motti/index-en.htm). Dynamic Vegetation Models can also be applied, (Lagergren et al 2017) have employed the LPJ-GUESS to assess the harvested biomass within forests, among three climatic areas in Sweden (Northern boreal, southern boreal and nemoral).

\subsection{Soil Conservation}

The vegetative cover plays an important role in soil retention, the prevention of landslides, the erosion regulation (MEA, 2005) and the reduction of fertility loss (xue et al 2001). The functional value of soil protection can be estimated by an approach used to value the soil protection function of the Chilean temperate forests by (Nahuelhuel et al 2007) that consists of assessing the extent of loss of soil nutrients due to soil erosion. However, this necessitate field level data on nutrient composition of forest soils, which is not always attainable (Ninan et al 2013b).Otherwise, (Roce-Diaz et al 2018) have used data from a highly detailed LULC map to estimate flood protection and erosion control of a riparian forest cover in Catalonia.

\subsection{Recreation}

Forests are also valued for the many recreational benefits they afford, such as viewing wildlife and nature, safari hunting, boating and angling, hiking, etc (Ninan et al 2016). These services are not traded in regular markets and do not have a market price to be used in the economic valuation exercise. This requires the use of specific techniques called "non-market valuation approaches" (Hanley et al., 1998; Scarpa et al., 2000; Horton et al., 2003). They aim to assess the individual willingness to pay (WTP) for using and enjoying the resource. (Ding et al 2016).(Ninan et al 2016;Roce-Diaz et al 2018) have employed the Travel Cost (TC) and Benefit Transfer (BT) approaches. The TC method uses data on actual costs incurred by visitors to recreation sites to estimate the visitor demand for recreation, while BT approach is employed when data are not available or too expensive, in this case they resort to studies already completed in another location or context.

\subsection{Trade-offs between Forest Ecosystem services:}

Trade-offs occur when the provision of one Ecosystem Service (ES) is reduced as a consequence of increased use of another ES (Rodríguez et al., 2006). Their dependence on each other and their complexity made managing them a principal challenge (Heal et al 2001). ES trade-offs can be classified into three axes: spatial scale (the expansion of the effects of trade-offs), temporal scale (if the effects take place relatively rapidly or slowly) and reversibility (the likelihood that the perturbed ES may return to its original state if the perturbation ends) (Rodriguez et al 2006).

The biggest challenge in forest management is to simultaneously maintain the timber production, the biodiversity, the regulation of carbon stocks and recreational services (De Groot et al 2010). Developing relevant methods for the identification of patterns towards sustainability is needed to study the conflicts between ES and to solve them by management scenarios. (Lagergren et al 2017).

(Trivino et al 2015) have simulated forest growth in a landscape with about 30,000 stands during 50 years, considering seven alternative management regimes in a large boreal forest production landscape. They have applied multi-objective optimisation to recognise where the current management actions are inefficient to supply multiple goods and services such as timber production or carbon storage. These analyses can also identify situations where carbon storage can be increased without any, or with only minimal reductions in the production of timber, or vice versa. Spatial representation of forest stands was executed within the Geographical Information System (GIS) software ArcGIS 10.1 (ESRI, 2011) and all the statistical analyses were performed using R version 3.0.2 (R Development Core Team, 2013).

In the same way (Pohjanmies et al 2017) have studied the compromise between four ecosystem services (timber production, bilberry production, carbon storage and pest regulation), one biodiversity conservation objective (availability of deadwood resources) and the potential to solve them by management choices in boreal production forests. They have firstly conducted a forest growth simulation within MOTTI stand simulator. Then they have measured the supply of each objective and the conflicts among all pairs of objectives under alternative forest management regimes. The compromise management solution (defined as one which simultaneously minimizes the losses in both objectives) for each pairwise conflict was determined before investigating the distribution of alternative forest management regimes among them.

Otherwise, the employment of Dynamic vegetation models (DVM) become frequent, essentially to assess climate and environmental effects on the performance of plant functional types or species, suitable for examining temporal aspects of ecosystem structure and functioning (Prentice et al 2007). (Lagergren et al 2017) have used the LPJ-GUESS to provide a landscape perspective among a boreal forest. They have tried to assess the influence of landscape settings; climate conditions and the forest stand management strategies, then they have developed a post-processing optimization routine to evaluate the combination of management alternatives at the landscape level. Provisioning services were represented by harvest of timber and pulp quantified in term of net income, regulating and maintenance services were symbolized by carbon storage and sequestration with three different measures (Carbon storage, biomass sequestration, soil carbon sequestration), while storm damage resistance was included to assess potential trade-offs between production and risk taking. Cultural ecosystem services were described by four indices (Fraction of broad-leafed forest, old trees, old broad-leafed trees, stem litter) serving as proxy for biodiversity (Mace et al 2012).

In order to explain how changes in climate conditions impact the provision of ES on European forests, (Ding et al 2016) have moved forward to explore methodologies that can examine the 
relationship between them. They have firstly assessed the amplitude of changes in the biophysical provision of ES (wood forest products, carbon sequestration and cultural services) .It represent different types of economics benefit due to potential impacts of climate change under four different IPCC future scenarios (Global economic, regional economic, global environment, regional environment) using Had-CM3 climate model, ATEAM (Advanced Terrestrial Ecosystem Analysis and Modelling) and IMAGE 2.2 models (Schöter et al., 2004), and then interpret them into economic values by undertaking an empirical application of diverse economic valuation techniques utilizing meta-analysis approaches.

Roce-Diaz et al., (2018) have introduced the spatial scale to assess trade-offs and synergies among three categories of ES (Provisioning, regulating and cultural).For each category a set of bio-physical indicators was defined and related to socioeconomic, climatic and biodiversity predictors .Data were provided by the Statistical Institute of Catalonia (IDESCAT, 2015) and aggregated at the municipality level. Proximity-totarget approach was used to normalize ES values to a conventional 0-1 scale to facilitate the analyze of relationships amongst pairs of ES(Rodríguez-Loinaz et al., 2015). The spatial correlation between standardized ES and the different indicators was examined by Pearson Correlations (Mouchet et al., 2014) while the spatial aggregation of each ES was evaluated using Moran's I on a Spatial Autocorrelation Analysis (Moran, 1948; ESRI, 2013).All statistical analyses were run in $\mathrm{R}$ software environment (v.3.2.0; R Development Core Team, 2014).Furthermore, a hotspot analysis on ES maps was carried out using the Getis-Ord Gi* clustering method (Getis and Ord, 1992; Schröter and Remme, 2016) to define the areas with optimum supply of the diverse categories of ES.

\section{DISCUSSION AND CONCLUSION}

This work sought to highlight studies examining trade-offs between Forest Ecosystem Services, to pinpoint relevant approaches and examine their shortcomings. Seven recent research aiming to assess environmental and economical benefits of FES were selected. Approaches used in those case studies vary from biophysical methods to monetary techniques. Biophysical methods include direct measurements were data are extracted from inventories, surveys and remote sensing. It also comprises indirect measurements that involve data derived from an original source and processed before being used. They also consist on modelling frameworks that use prior cited source of data as inputs.

Generally, researchers combine several methods when trying to explore trade-offs among various FES.They base their choice by relying on 1)the studied forest service ,2)the existence of elementary data,3)the spatial and temporal scale appropriateness, 4)the relevance and adequacy of models. The majority of studies converge to apply models with the purpose of simulating the FES supply or predicting the impact of climate change on the functioning of the ES.Softwares used for modelling are usually commercial or need extensive data. Some of them are cost-free but are proper to a particular area, a climatic region or a singular type of forests.

Accuracy is also an important factor while assessing trade-offs. Indirect measurement methods are based on processed primary data, which are essentially governed by the statistical data analysis approach used. It's obvious that an erroneous input would affect the whole results, and consequently the management intervention.
Method selection should consider the real-life aspects, the context, the ecosystem services in question, the strengths and shortcomings of diverse approaches, data availability, resource and expertise (Harrison et al,2018)

\section{REFERENCES}

Bradford, J. B., \& D'Amato, A. W. (2012). Recognizing tradeoffs in multi-objective land management. Frontiers in Ecology and the Environment, 10(4), 210-216.

Brandt, P., Abson, D. J., DellaSala, D. A., Feller, R., \& von Wehrden, H. (2014). Multifunctionality and biodiversity: Ecosystem services in temperate rainforests of the Pacific Northwest, USA. Biological Conservation, 169, 362-371.

Brandt, P., Abson, D. J., DellaSala, D. A., Feller, R., \& von Wehrden, H. (2014). Multifunctionality and biodiversity : Ecosystem services in temperate rainforests of the Pacific Northwest, USA. Biological Conservation, 169, 362-371.

Brown, S., \& Lugo, A. E. (1982). The storage and production of organic matter in tropical forests and their role in the global carbon cycle. Biotropica, 14(3), 161-187.

Brown, S. (1993). Tropical forests and the global carbon cycle: the need for sustainable land-use patterns. Agriculture, Ecosystems \& Environment, 46(1-4), 31-44.

Brown, S. (1997). Estimating biomass and biomass change of tropical forests: a primer (Vol. 134). Food \& Agriculture Org.

Chave, J., Andalo, C., Brown, S., Cairns, M. A., Chambers, J. Q., Eamus, D., ... \& Lescure, J. P. (2005). Tree allometry and improved estimation of carbon stocks and balance in tropical forests. Oecologia, 145(1), 87-99.

Chave, J., Réjou-Méchain, M., Búrquez, A., Chidumayo, E., Colgan, M. S., Delitti, W. B., ... \& Henry, M. (2014). Improved allometric models to estimate the aboveground biomass of tropical trees. Global change biology, 20(10), 3177-3190.

Chiabai, A., Travisi, C. M., Markandya, A., Ding, H., \& Nunes, P. A. (2011). Economic assessment of forest ecosystem services losses: cost of policy inaction. Environmental and Resource Economics, 50(3), 405-445.

De Groot, R. S., \& van der Meer, P. J. (2010). Quantifying and valuing goods and services provided by plantation forests. In Ecosystem goods and services from plantation forests (pp. 3258). Routledge.

De Groot, R. S., Alkemade, R., Braat, L., Hein, L., \& Willemen, L. (2010). Challenges in integrating the concept of ecosystem services and values in landscape planning, management and decision making. Ecological complexity, 7(3), 260-272.

Ding, H., Chiabai, A., Silvestri, S., \& Nunes, P. A. (2016). Valuing climate change impacts on European forest ecosystems. Ecosystem services, 18, 141-153. 
ESRI, 2011. ArcGIS Desktop: Release 10. Environmental Systems Redlands, CA Research Institute,

ESRI, 2013b. How Spatial Autocorrelation (Global Moran's I) works. [online] URL: http:// resources.arcgis.com/en/help/main/10.1/index.html\#//005p0000 000t000000.

Fischer, J., Lindenmayer, D. B., \& Manning, A. D. (2006). Biodiversity, ecosystem function, and resilience: ten guiding principles for commodity production landscapes. Frontiers in Ecology and the Environment, 4(2), 80-86.

Gamfeldt, L., Snäll, T., Bagchi, R., Jonsson, M., Gustafsson, L., Kjellander, P., ... \& Mikusiński, G. (2013). Higher levels of multiple ecosystem services are found in forests with more tree species. Nature communications, 4, 1340.

García-Nieto, A. P., García-Llorente, M., Iniesta-Arandia, I., \& Martín-López, B. (2013). Mapping forest ecosystem services: from providing units to beneficiaries. Ecosystem Services, 4, 126-138.

Getis, A., Ord, J.K., 1992. The analysis of spatial association. Geogr. Anal. 24, 189-206

Gibbs, H. K., Brown, S., Niles, J. O., \& Foley, J. A. (2007). Monitoring and estimating tropical forest carbon stocks: making REDD a reality. Environmental Research Letters, 2(4), 045023.

Gracia C, Burriel JA, Iba`ñez JJ, Mata T, Vayreda J (2004a) Inventari Ecolo`gic i Forestal de Catalunya. Me`todes. Volum 9. CREAF, Bellaterra.

Gracia C, Burriel JA, Iba`ñez JJ, Mata T, Vayreda J (2004b) Inventari Ecolo'gic i Forestal de Catalunya. Catalunya. Volum 10. CREAF, Bellaterra

Hanley, N., Wright, R. E., \& Adamowicz, V. (1998). Using choice experiments to value the environment. Environmental and resource economics, 11(3-4), 413-428.

Harrison, P. A., Dunford, R., Barton, D. N., Kelemen, E., Martín-López, B., Norton, L., ... \& Czúcz, B. (2018). Selecting methods for ecosystem service assessment: A decision tree approach. Ecosystem services, 29, 481-498.

Heal, G., Daily, G. C., Ehrlich, P. R., \& Salzman, J. (2001). Protecting natural capital through ecosystem service districts. Stan. Envtl. LJ, 20, 333.

Horton, B., Colarullo, G., Bateman, I. J., \& Peres, C. A. (2003). Evaluating non-user willingness to pay for a large-scale conservation programme in Amazonia: a UK/Italian contingent valuation study. Environmental Conservation, 30(2), 139-146.

Houghton, R. A., House, J. I., Pongratz, J., Van Der Werf, G. R., DeFries, R. S., Hansen, M. C., ... \& Ramankutty, N. (2012). Carbon emissions from land use and land-cover change. Biogeosciences, 9(12), 5125-5142.
IDESCAT, Institut dEstadística de Catalunya. 2015. Información demográfica y económica por municipios. Consulta on-line. http://www.idescat.cat/es/

IPCC (Intergovernmental Panel on Climate Change). (2001). Climate Change 2001: the scientific basis. Contribution of working group I to the third assessment report of the Intergovernmental Panel on Climate Change.

IPCC, 2006. IPCC guidelines for national greenhouse gas inventories. In: Eggleston, H., Buendia, L., Miwa, K., Ngara, T., Tanabe, K. (Eds.), Prepared by the National Greenhouse Gas Inventories Programme. Institute for Global Environmental Strategies, Japan.

Kotlarski, S., Keuler, K., Christensen, O. B., Colette, A., Déqué, M., Gobiet, A., ... \& Nikulin, G. (2014). Regional climate modeling on European scales: a joint standard evaluation of the EURO-CORDEX RCM ensemble. Geoscientific Model Development, 7, 1297-1333.

Lagergren, F., \& Jönsson, A. M. (2017). Ecosystem model analysis of multi-use forestry in a changing climate. Ecosystem services, 26, 209-224.

Law, E. A., Bryan, B. A., Torabi, N., Bekessy, S. A., McAlpine, C. A., \& Wilson, K. A. (2015). Measurement matters in managing landscape carbon. Ecosystem services, 13, 6-15.

Liebhold, A. M., Brockerhoff, E. G., Kalisz, S., Nuñez, M. A., Wardle, D. A., \& Wingfield, M. J. (2017). Biological invasions in forest ecosystems. Biological invasions, 19(11), 3437-3458.

Mace, G. M., Norris, K., \& Fitter, A. H. (2012). Biodiversity and ecosystem services: a multilayered relationship. Trends in ecology \& evolution, 27(1), 19-26.

Millennium Ecosystem Assessment, M. E. A. (2005). Ecosystems and human well-being. Synthesis.

Moran, P. A. (1948). The interpretation of statistical maps. Journal of the Royal Statistical Society. Series B (Methodological), 10(2), 243-251.

Mouchet, M. A., Lamarque, P., Martín-López, B., Crouzat, E., Gos, P., Byczek, C., \& Lavorel, S. (2014). An interdisciplinary methodological guide for quantifying associations between ecosystem services. Global environmental change, 28, 298-308.

Nahuelhual, L., Donoso, P., Lara, A., Nuñez, D., Oyarzun, C., \& Neira, E. (2007). Valuing ecosystem services of Chilean temperate rainforests. Environment, Development and Sustainability, 9(4), 481-499.

Ninan, K. N., \& Inoue, M. (2013). Valuing forest ecosystem services: Case study of a forest reserve in Japan. Ecosystem Services, 5, 78-87.

Ninan, K. N., \& Kontoleon, A. (2016). Valuing forest ecosystem services and disservices-Case study of a protected area in India. Ecosystem services, 20, 1-14. 
Penman, J., Gytarsky, M., Hiraishi, T., Krug, T., Kruger, D., Pipatti, R., ... \& Wagner, F. (2003). Good practice guidance for land use, land-use change and forestry. Good practice guidance for land use, land-use change and forestry.

Pohjanmies, T., Triviño, M., Le Tortorec, E., Salminen, H., \& Mönkkönen, M. (2017). Conflicting objectives in production forests pose a challenge for forest management. Ecosystem Services, 28, 298-310.

Powers, E. M., Marshall, J. D., Zhang, J., \& Wei, L. (2013). Post-fire management regimes affect carbon sequestration and storage in a Sierra Nevada mixed conifer forest. Forest Ecology and Management, 291, 268-277.

Prentice, I. C., Bondeau, A., Cramer, W., Harrison, S. P., Hickler, T., Lucht, W., ... \& Sykes, M. T. (2007). Dynamic global vegetation modeling: quantifying terrestrial ecosystem responses to large-scale environmental change. In Terrestrial ecosystems in a changing world (pp. 175-192). Springer, Berlin, Heidelberg.

R Development Core Team, 2013. R: A Language and Environment for Statistical Computing., Vienna, Austria. Available at: 〈http://www.R-project.org

R Development Core Team. R: A Language and Environment for Statistical Computing. Vienna, Austria: R Foundation for Statistical Computing; 2014

Rapport, D. J., Costanza, R., \& McMichael, A. J. (1998). Assessing ecosystem health. Trends in ecology \& evolution, 13(10), 397-402.

Roces-Díaz, J. V., Vayreda, J., Banqué-Casanovas, M., Cusó, M., Anton, M., Bonet, J. A., ... \& de-Miguel, S. (2018). Assessing the distribution of forest ecosystem services in a highly populated Mediterranean region. Ecological indicators, 93, 986-997.

Rodríguez, J. P., T. D. Beard, Jr., E. M. Bennett, G. S. Cumming, S. Cork, J. Agard, A. P. Dobson, and G. D. Peterson. 2006. Trade-offs across space, time, and ecosystem services. Ecology and Society 11(1): 28

Rodríguez-Loinaz, G., Alday, J. G., \& Onaindia, M. (2015). Multiple ecosystem services landscape index: a tool for multifunctional landscapes conservation. Journal of environmental management, 147, 152-163.

Ruddell, S., Sampson, R., Smith, M., Giffen, R., Cathcart, J., Hagan, J., ... \& Helms, J. (2007). The role for sustainably managed forests in climate change mitigation. Journal of Forestry, 105(6), 314-319.

Saatchi, S. S., Houghton, R. A., Dos Santos Alvala, R. C., Soares, J. V., \& Yu, Y. (2007). Distribution of aboveground live biomass in the Amazon basin. Global change biology, 13(4), 816-837.

Scarpa, R., Chilton, S. M., Hutchinson, W. G., \& Buongiorno, J. (2000). Valuing the recreational benefits from the creation of nature reserves in Irish forests. Ecological Economics, 33(2), 237-250.

Schröter, D., Cramer, W., Leemans, R., Prentice, I. C., Araújo, M. B., Arnell, N. W., ... \& Anne, C. (2005). Ecosystem service supply and vulnerability to global change in Europe. science, 310(5752), 1333-1337.

Schröter, M., \& Remme, R. P. (2016). Spatial prioritisation for conserving ecosystem services: comparing hotspots with heuristic optimisation. Landscape ecology, 31(2), 431-450.

Smith, B., Prentice, I. C., \& Sykes, M. T. (2001). Representation of vegetation dynamics in the modelling of terrestrial ecosystems: comparing two contrasting approaches within European climate space. Global Ecology and Biogeography, 10(6), 621-637.

Tol, R. S. (2009). The economic effects of climate change. Journal of economic perspectives, 23(2), 29-51.

Triviño, M., Juutinen, A., Mazziotta, A., Miettinen, K., Podkopaev, D., Reunanen, P., \& Mönkkönen, M. (2015). Managing a boreal forest landscape for providing timber, storing and sequestering carbon. Ecosystem Services, 14, 179-189.

Vanhanen, H., Jonsson, R., Gerasimov, Y., Krankina, O., \& Messieur, C. (2012). Making boreal forests work for people and nature.

Vayreda, J., Martinez-Vilalta, J., Gracia, M., Retana, J., 2012. Recent climate changes interact with stand structure and management to determine changes in tree carbon stocks in Spanish forests. Glob. Chang. Biol. 18, 1028-1041.

Vitousek, P. M. (1997). Human domination of earth ecosystems (vol 277, Pg 494, 1997). Science, 278(5335), 21-21.

Wagner, S., Nocentini, S., Huth, F., \& Hoogstra-Klein, M. (2014). Forest management approaches for coping with the uncertainty of climate change: trade-offs in service provisioning and adaptability. Ecology and Society, 19(1).

Waring, R. H., Way, J., Hunt, E. R., Morrissey, L., Ranson, K. J., Weishampel, J. F., ... \& Franklin, S. E. (1995). Imaging radar for ecosystem studies. BioScience, 45(10), 715-723.

Westlake, D. F. (1966). The biomass and productivity of glyceria maxima: I. Seasonal changes in biomass. The Journal of Ecology, 745-753.

Xue, D., \& Tisdell, C. (2001). Valuing ecological functions of biodiversity in Changbaishan Mountain Biosphere Reserve in northeast China. Biodiversity \& Conservation, 10(3), 467-481. 